Article

\title{
The Central Negative Regulator of Flooding Tolerance, the PROTEOLYSIS 6 Branch of the N-degron Pathway, Adversely Modulates Salinity Tolerance in Arabidopsis
}

\author{
Suman Lamichhane ${ }^{1,2}{ }^{(D}$, Jasper B. Alpuerto ${ }^{1,2}$, Abigail Han ${ }^{1}$ and Takeshi Fukao ${ }^{1,3, *(\mathbb{C}}$ \\ 1 School of Plant and Environmental Sciences, Virginia Tech, Blacksburg, VA 24061, USA; \\ sumanl7@vt.edu (S.L.); Jasper.Alpuerto@ag.tamu.edu (J.B.A.); ahan@vt.edu (A.H.) \\ 2 Texas A \& M Agrilife Research, Beaumont, TX 77713, USA \\ 3 Department of Bioscience and Biotechnology, Fukui Prefectural University, Eiheiji, Fukui 910-1195, Japan \\ * Correspondence: fukao@fpu.ac.jp
}

Received: 10 October 2020; Accepted: 21 October 2020; Published: 23 October 2020

check for updates

\begin{abstract}
Seawater intrusion in coastal regions and waterlogging in salinized lands are serious constraints that reduce crop productivity under changing climate scenarios. Under these conditions, plants encounter flooding and salinity concurrently or sequentially. Identification and characterization of genes and pathways associated with both flooding and salinity adaptation are critical steps for the simultaneous improvement of plant tolerance to these stresses. The PROTEOLYSIS 6 (PRT6) branch of the N-degron pathway is a well-characterized process that negatively regulates flooding tolerance in plants. Here, we determined the role of the PRT6/N-degron pathway in salinity tolerance in Arabidopsis. This study demonstrates that the prt6 mutation enhances salinity tolerance at the germination, seedling, and adult plant stages. Maintenance of chlorophyll content and root growth under high salt in the prt6 mutant was linked with the restricted accumulation of sodium ions $\left(\mathrm{Na}^{+}\right)$in shoots and roots of the mutant genotype. The prt6 mutation also stimulated mRNA accumulation of key transcription factors in ABA-dependent and independent pathways of osmotic/salinity tolerance, accompanied by the prominent expression of their downstream genes. Furthermore, the prt6 mutant displayed increased sensitivity to ethylene and brassinosteroids, which can suppress $\mathrm{Na}^{+}$uptake and promote the expression of stress-responsive genes. This study provides genetic evidence that both salinity and flooding tolerance is coordinated through a common regulatory pathway in Arabidopsis.
\end{abstract}

Keywords: Arabidopsis thaliana; brassinosteroids; ethylene; N-degron pathway; PRT6; salinity

\section{Introduction}

Most commercially important plants are susceptible to high salt levels. Therefore, soil salinization is a serious constraint that threatens food security worldwide. Currently, more than $6 \%$ of the total land surface and $20 \%$ of the total irrigated areas are affected by excess salt, a condition that is increasingly widespread [1]. To meet growing demands for plant-based products at the global level, it is imperative to improve salinity tolerance in major crops.

Plants encounter multiple abiotic stresses simultaneously or sequentially in an agricultural or natural environment. In the context of salinity stress, plants can be exposed to excess salt and water as a consequence of flooding in salinized areas and seawater intrusion in coastal regions. Importantly, much of the world's saline land is subjected to flooding because of shallow water tables and low infiltration of surface water [2]. It has been predicted that a rise in the sea level and elevated frequency of storm surges will increase seawater inundation in low-lying grasslands and croplands, leading to 
serious agricultural losses in coastal zones [3-5]. For these reasons, there is an urgent need for the development of new crop varieties with enhanced tolerance to both salinity and flooding.

Identification and functional characterization of genes and pathways associated with adaptation to both salinity and flooding are critical steps for the simultaneous improvement of plant tolerance to these stresses. In this study, we evaluated whether a well-characterized signaling pathway involved in flooding tolerance, the PROTEOLYSIS 6 (PRT6) branch of the N-degron pathway, regulates adaptation to high salt. The $\mathrm{N}$-degron pathway is an enzymatic cascade that determines the half-life of protein substrates depending on the identity of their N-terminal residues [6,7]. In the PRT6 branch of the $\mathrm{N}$-degron pathway, PRT6, an E3 ubiquitin ligase, is the last enzyme that recognizes the specific $\mathrm{N}$-terminal residues of its substrates, which are subsequently ubiquitinated and transported into the $26 \mathrm{~S}$ proteasome for degradation [8].

Diverse biological roles of the PRT6/N-degron pathway have been revealed through genetic analysis of loss-of-function mutants of prt6 and other enzymes of this pathway. Such roles include the regulation of seed dormancy and germination, seedling establishment, leaf and root development, photomorphogenesis, leaf senescence, and disease resistance as well as flooding/low oxygen tolerance [9-20]. Genetic evidence obtained from these studies suggests that proper modulation of regulatory protein levels via the PRT6/N-degron pathway coordinates these traits. Nevertheless, only a limited number of the PRT6/N-degron substrates have been identified; the most characterized of these being the group VII Ethylene Response Factor (ERF-VII) transcription factors.

The Arabidopsis genome encodes five ERF-Vll genes, all of which play a pivotal role in the expression of core hypoxia-responsive genes and tolerance to flooding and low oxygen [21,22]. The half-life of these transcription factor proteins is controlled by sequential reactions in the PRT6/N-degron pathway. All ERF-VII transcription factors contain a highly conserved $\mathrm{N}$-terminal motif that is initiated with methionine (Met) and cysteine (Cys) residues [12,13]. First, the N-terminal Met is cleaved by methionine aminopeptidase. Next, the exposed Cys is oxidized by plant cysteine oxidases (PCOs) in an oxygen and nitric oxide-dependent manner [14,15]. The oxidized Cys is then arginylated by arginyl-tRNA transferases. Finally, the N-terminally modified ERF-VII proteins are ubiquitinated by PRT6, which are targeted for proteasomal degradation [8]. Due to the oxygen requirement for PCOs, low oxygen and flooding allow ERF-VII proteins to escape from this proteolysis pathway, thereby triggering the expression of hypoxia-responsive genes. Consistently, disruption of the PRT6/N-degron pathway in ate1ate 2 and prt6 mutants promotes transcript accumulation of core hypoxia-responsive genes and confers tolerance to oxygen deprivation and submergence [12,15]. It was predicted that the PRT6/N-degron pathway catalyzed substrates other than ERF-VIIs [23]. In fact, a polycomb repressive complex 2 subunit VERNALIZATION 2 (VRN2) and a small leucine zipper-containing protein LITTLE ZIPPER 2 (ZPR2) were recently identified as new N-degron targets in Arabidopsis [24,25].

In the present study, we assessed the role of the PRT6/N-degron pathway, a key regulatory process of flooding tolerance, in adaptation to salinity stress in Arabidopsis through physiological and molecular characterization of the prt6-1 mutant. Recently, it was reported that the prt6 mutation enhances seedling survival under high salt [26]. However, the influence of the mutated gene in salt tolerance at other developmental stages and its adaptation mechanisms remain obscure. Here, we investigated the contribution of the prt6 mutation to salinity tolerance and relevant traits in Arabidopsis at various growth stages. Detailed time-course and dose-response analyses uncovered a negative role of the PRT6/N-degron pathway in transcriptional, hormonal, and physiological adaptations to excess salt. This study provides genetic evidence that both flooding and salinity tolerance is coordinated through a common regulatory pathway in Arabidopsis. 


\section{Results}

\subsection{The prt6 Mutation Enhances Salinity Tolerance at Various Developmental Stages}

To determine the role of the prt6 mutant in salinity tolerance at different growth stages, we performed various stress tolerance evaluations. First, we assessed seed germination performance under moderate (sub-lethal) salinity ( $\leq 150 \mathrm{mM} \mathrm{NaCl}$ ) (Figure 1A). Salinity stress reduced seed germination of both wild-type (WT) and mutant genotypes in a dose-dependent manner, but prt6 seeds germinated more vigorously at 100 and $150 \mathrm{mM} \mathrm{NaCl}$. Consistently, the time-course observation demonstrated that prt6 seeds germinated more readily than WT on days 3, 4, and 5 (Figure 1B).

A

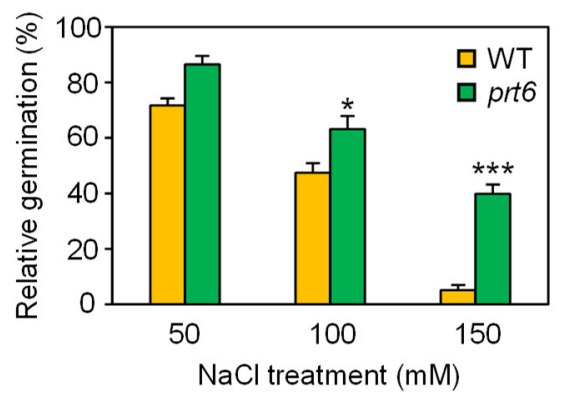

C

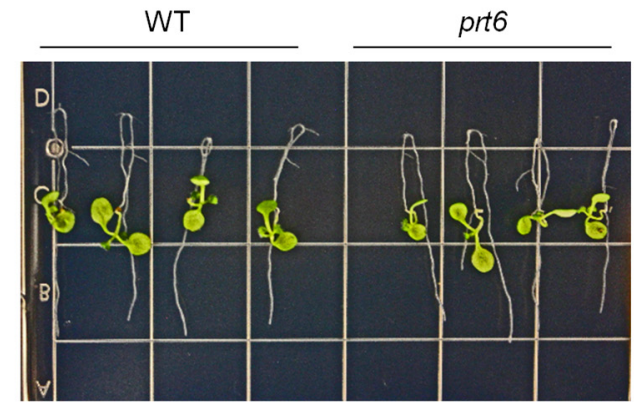

Control

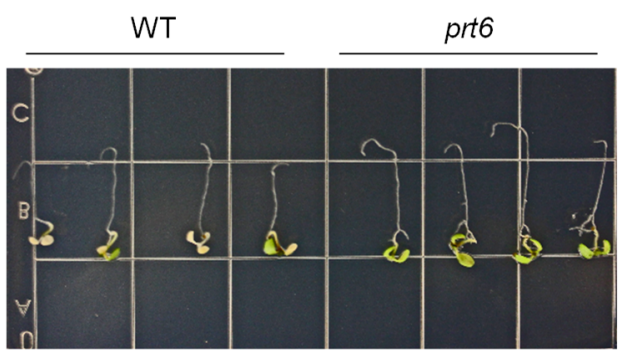

$150 \mathrm{mM} \mathrm{NaCl}$
B

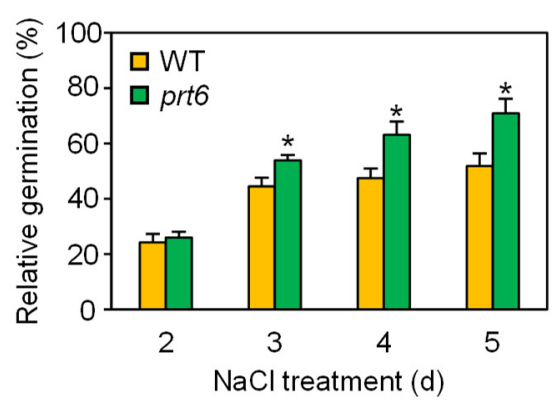

D

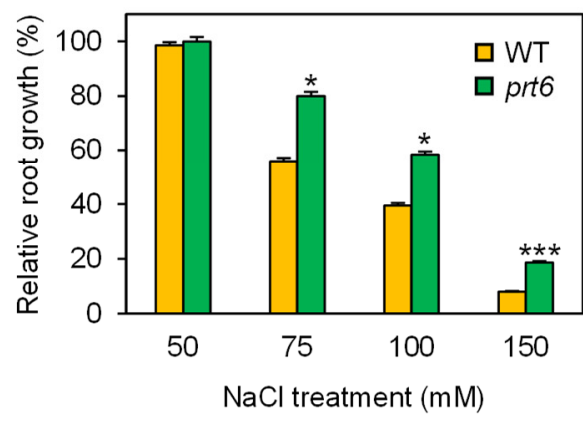

Figure 1. Loss-of-function mutation of prt6 enhanced tolerance to moderate (sublethal) salinity at the seed germination and seedling stages. (A) Dose-response of wild-type (WT) and prt6 seeds to $\mathrm{NaCl}$ during seed germination. Seeds were incubated under sublethal levels of $\mathrm{NaCl}(\leq 150 \mathrm{mM})$ for $4 \mathrm{~d}$. (B) Time-course observation of seed germination in WT and prt6 seeds under sublethal salinity. Seeds were incubated under $100 \mathrm{mM} \mathrm{NaCl}$ for up to $5 \mathrm{~d}$. (C) Photos of WT and prt6 seedlings that were grown upside down under non-stress or moderate salinity. Four-day-old seedlings grown under non-stress conditions were transferred on half-strength MS plates containing 0 or $150 \mathrm{mM} \mathrm{NaCl}$ and incubated upside down for $4 \mathrm{~d}$. (D) Dose-response of WT and prt6 root growth to moderate salinity. Four-day-old seedlings were grown vertically on half-strength MS plates containing a range of $\mathrm{NaCl}$ concentrations for $4 \mathrm{~d}$. Relative germination and root growth in (A), (B), and (D) were calculated by comparison to non-stressed WT or prt6. Data represent means \pm SE $[\mathrm{n}=3$ in $(\mathbf{A}, \mathbf{B}) ; \mathrm{n}=24$ in (D)]. Asterisks indicate significant difference between WT and prt6 $\left.{ }^{*} p<0.05 ;{ }^{* * *} p<0.001\right)$. 
Next, we determined the ability of the prt6 mutant in root elongation under moderate salinity at the seedling stage. Well-established root bending assays $[27,28]$ were performed to demonstrate the effect of prt6 mutation on root elongation under salinity stress. In these assays, WT and prt6 seedlings displayed similar root elongation under control conditions, whereas roots of prt6 seedlings grew more vigorously than WT under salinity (Figure 1C). Quantitative assays of root elongation further supported that the prt6 mutation contributes to maintained root growth under moderate salinity (75-150 mM NaCl) (Figure 1D).

We also evaluated whether the prt6 mutation affects seedling viability under high (lethal) salinity. WT and prt6 seedlings showed identical growth under control conditions (Figure 2A). When exposed to high salinity $(200 \mathrm{mM} \mathrm{NaCl})$, more than $90 \%$ of WT seedling died, but the majority ( $>60 \%)$ of prt6 seedlings were viable (Figure 2A,B). Correspondingly, seedling biomass and leaf chlorophyll content were significantly higher in the prt6 mutant than WT under high salinity (Figure 2C,D).

A
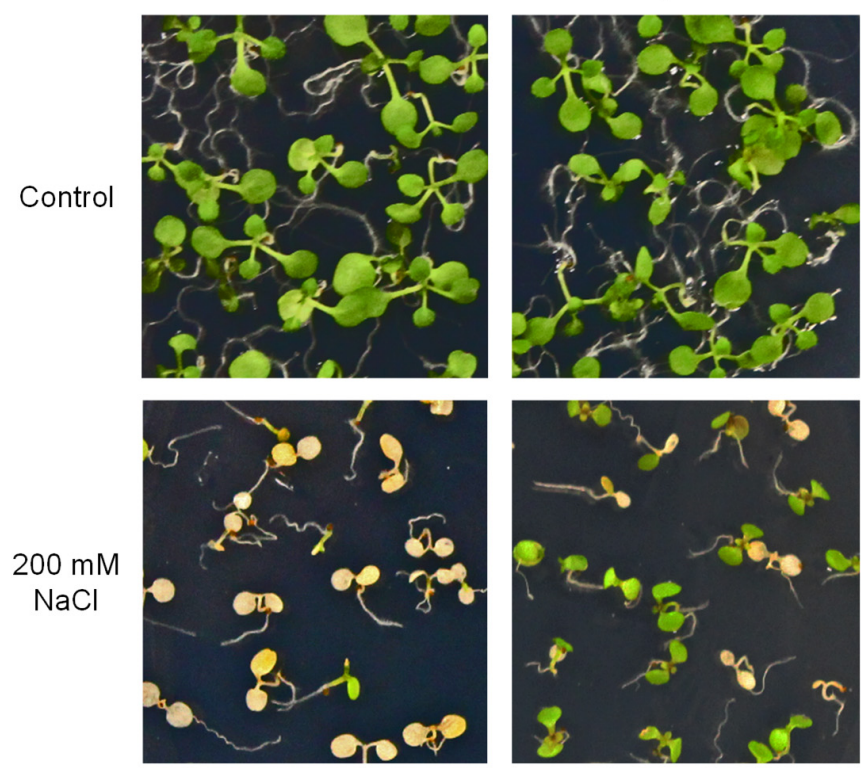

prt6

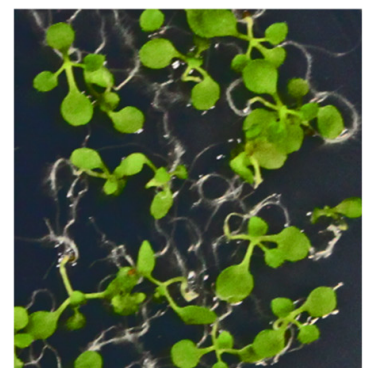

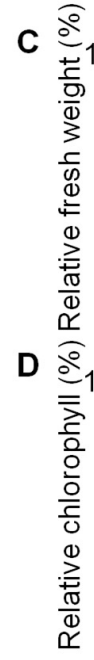
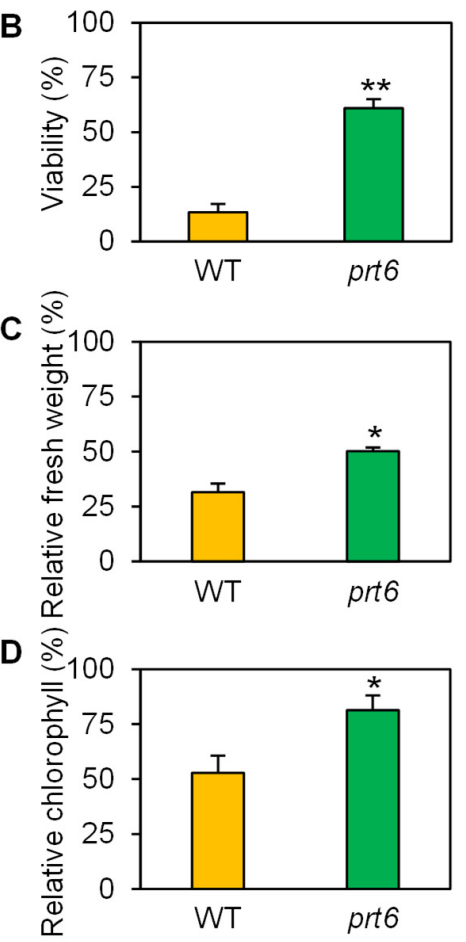

Figure 2. The prt6 mutation increased seedling viability under high salinity. (A) Photos of wild-type (WT) and prt6 mutant seedlings exposed to non-stress or high salinity conditions. Four-day-old seedlings were transferred onto half-strength MS media containing 0 or $200 \mathrm{mM} \mathrm{NaCl}$ and grown for $4 \mathrm{~d}$. Seedling viability (B), relative fresh weight (C), and relative chlorophyll content (D) of WT and prt6 seedlings under high salinity. Seedlings exposed to 0 or $200 \mathrm{mM} \mathrm{NaCl}$ as described in (A) were used for data collection in (B-D). Relative fresh weight and chlorophyll were calculated by comparison to non-stressed WT or prt6. Data represent means \pm SE $[n=3$ in (B-D)]. Asterisks indicate significant difference between WT and $p r t 6\left({ }^{*} p<0.05 ;{ }^{* *} p<0.01\right)$.

Finally, we analyzed adult-plant tolerance to high salinity. Under control conditions, prt6 plants displayed early senescence, relative to WT (Figure 3A). However, prt6 plants had more green leaves than WT under high salt. Consistent with the phenotypic observation, aboveground biomass and chlorophyll content were significantly higher in the prt6 mutant under salt stress (Figure 3C,D). In contrast with the chlorophyll data, anthocyanin was highly accumulated in WT plants (Figure 3D), indicating that WT suffered from more severe salinity damage. Taken together, the qualitative and quantitative data presented here demonstrated that loss-of-function mutation of prt6 increases salinity tolerance at the seed germination, seedling, and adult-plant stages. 
A
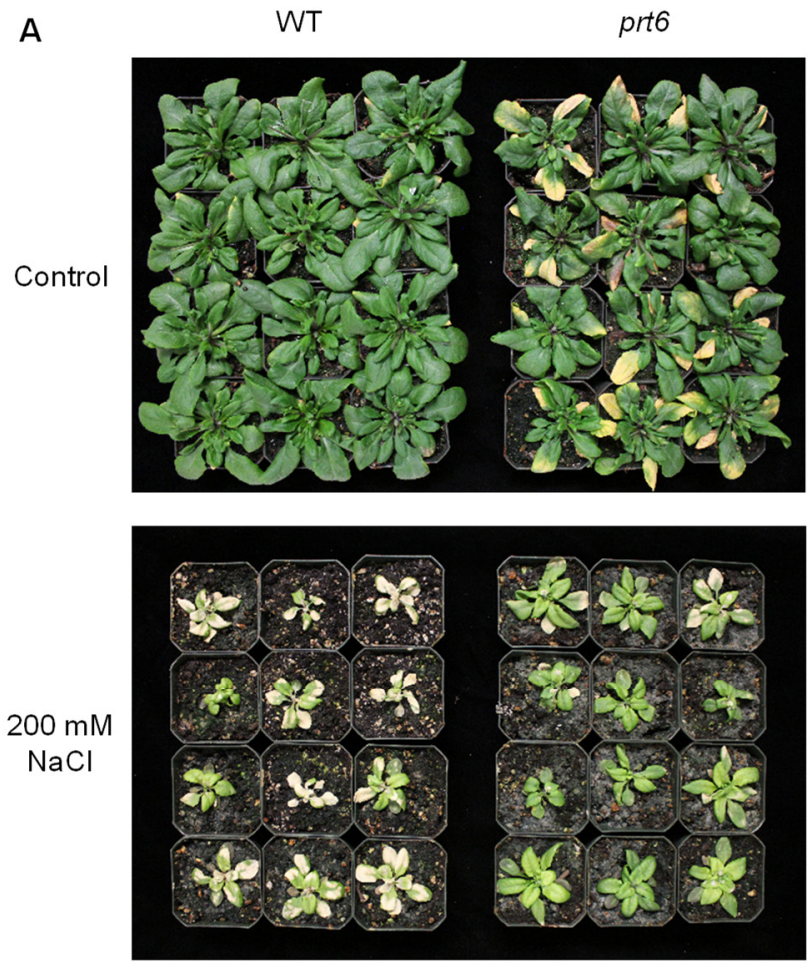

B

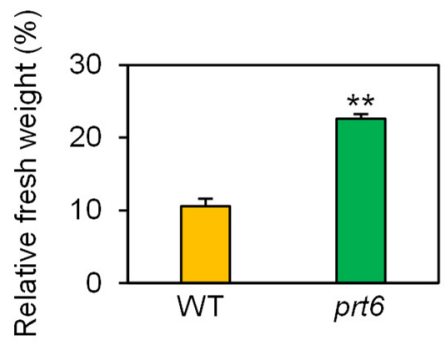

C

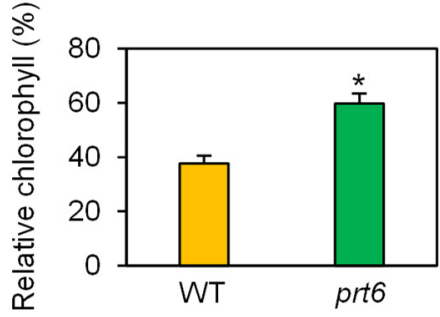

D

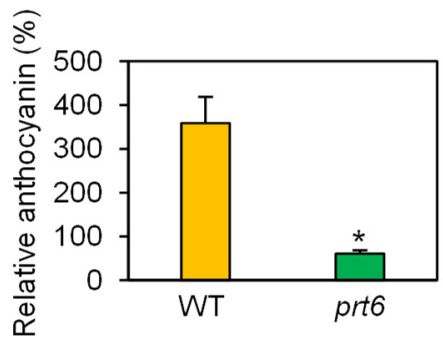

Figure 3. The prt6 mutation increased adult-plant tolerance to high salinity. (A) Photos of wild-type (WT) and prt6 plants exposed to non-stress or high salinity. Plants were grown in pots under regular growth conditions for $21 \mathrm{~d}$ and then irrigated with fertilized water containing 0 or $200 \mathrm{mM} \mathrm{NaCl}$ for $12 \mathrm{~d}$. Relative fresh weight (B), chlorophyll (C), and anthocyanin (D) of WT and prt6 plants exposed to salinity. These relative values were calculated by comparison to non-stressed WT or prt6. Data represent means $\pm \mathrm{SE}[\mathrm{n}=12$ in $(\mathbf{B}) ; \mathrm{n}=3$ in $(\mathbf{C}, \mathbf{D})]$. Asterisks indicate significant difference between WT and prt6 $\left({ }^{*} p<0.05 ;{ }^{* *} p<0.01\right)$.

\subsection{The prt6 Mutant Plants Show Restricted Accumulation of Sodium Ions $\left(\mathrm{Na}^{+}\right)$in Roots and Shoots}

Salinity-mediated reductions in chlorophyll content and root growth were less severe in the prt6 mutant than WT. We hypothesized that these results are attributed to a restricted accumulation of $\mathrm{Na}^{+}$ in the mutant line. To test this, we monitored the abundance of $\mathrm{Na}^{+}$in root and shoot tissues of plants exposed to salinity stress. This analysis revealed that the prt6 mutant contained a lower amount of $\mathrm{Na}^{+}$in both roots and shoots (Figure 4). In shoots, the effect of this mutant allele was still significant on day 5 , while this effect was not observed in roots at that time. These results suggest that the prt6 mutation contributes to the suppression of root-to-shoot $\mathrm{Na}^{+}$transport as well as $\mathrm{Na}^{+}$uptake into roots. Unlike $\mathrm{Na}^{+}$concentrations, the influence of the mutant allele in $\mathrm{K}^{+}$accumulation was minimal or not observed in roots and shoots (Figure 4 ). 

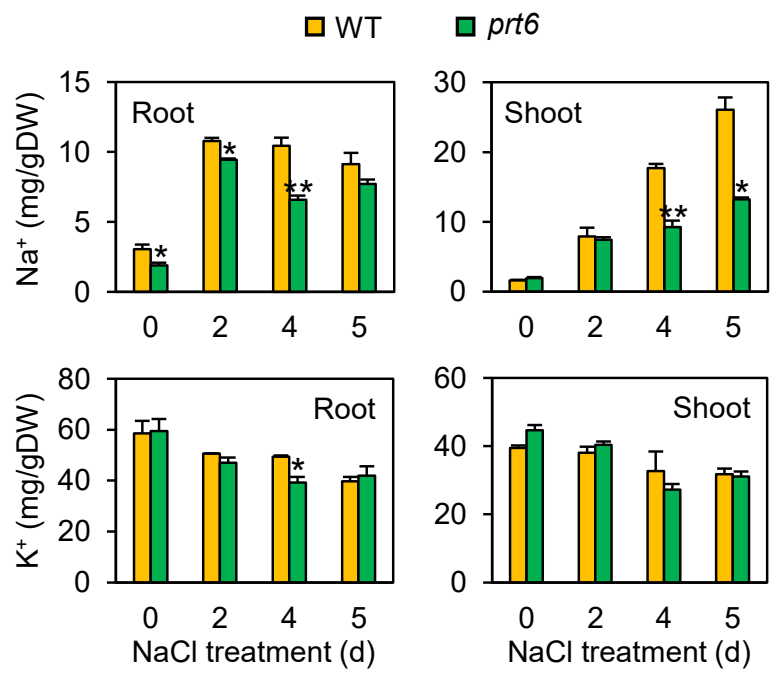

Figure 4. The prt6 mutation restricted accumulation of $\mathrm{Na}^{+}$in shoots and roots of Arabidopsis plants under salinity. Wild-type (WT) and prt6 plants were grown in Turface under regular growth conditions for $21 \mathrm{~d}$ and then irrigated with fertilized water containing $150 \mathrm{mM} \mathrm{NaCl}$ for up to $5 \mathrm{~d}$. Shoot and root samples were harvested at the specified time points, washed thoroughly, and subjected to $\mathrm{Na}^{+}$and $\mathrm{K}^{+}$ assays. Data represent means $\pm \mathrm{SE}(\mathrm{n}=3)$. Asterisks indicate significant difference between $\mathrm{WT}$ and prt6 $\left({ }^{*} p<0.05 ;{ }^{* *} p<0.01\right)$.

\subsection{The prt6 Mutation Augments Responsiveness to Ethylene and Brassinosteroids}

Ethylene and brassinosteroids (BR) are positive regulators for salinity tolerance in plants [29-32]. To discern the capability of the prt6 mutant in regulating sensitivity to these hormones, we performed hormone response assays. When incubated under constant darkness, prt6 mutant seedlings displayed moderate triple response phenotypes even without 1-aminocyclopropane-1-carboxylic acid (ACC), an immediate precursor of ethylene (Figure 5A). When ACC was supplied, more severe restriction of hypocotyl elongation and enhancement of apical hook formation were observed in the mutant seedlings. Dose-response analysis further supported that ACC-mediated reductions in hypocotyl growth were more significant in the prt6 mutant at all ACC concentrations tested (Figure 5B). We also evaluated the effect of the mutant allele on mRNA accumulation of ethylene-responsive genes. All the four representative marker genes, PLANT DEFENSIN 1.2 (PDF1.2), ACC OXIDASE 2 (ACO2), ERF1, and RELATED TO AP2.3 (RAP2.3) [33,34], were highly induced in response to ACC in the prt6 mutant, compared to WT (Figure 5C). These results indicate that the prt6 mutation leads to increased responsiveness to ethylene at the molecular and physiological levels.

We also examined the impact of the prt6 mutation on BR sensitivity. Both WT and prt6 seedlings grew similarly under mock (0.02\% ethanol) conditions (Figure 6A). Application of 24-epibrassinolide (eBL), a bioactive BR, considerably limited root growth in the two genotypes, with a more severe reduction in the mutant seedlings. Dose-dependent analysis verified that root elongation was inhibited to a greater degree by 0.1 and $1 \mu \mathrm{M}$ eBL in the prt6 mutant than WT. BR responsiveness in WT and the prt6 mutant was further evaluated by expression analysis of BR-responsive genes. All the four marker genes, PHYB ACTIVATION TAGGED SUPPRESSOR 1 (BAS1), PECTIN ACETYLESTERASE 8 (PAE8), XYLOGLUCAN: XYLOGLUCOSYL TRANSFERASE 33 (XTH33), and SMALL AUXIN UP RNA_Ac1 (Saur_Ac1) [35,36], were expressed more abundantly in the mutant line than WT when treated with $1 \mu \mathrm{M}$ eBL (Figure 6C). Altogether, these data demonstrated that the prt6 mutation contributes to amplified sensitivity to BR. 

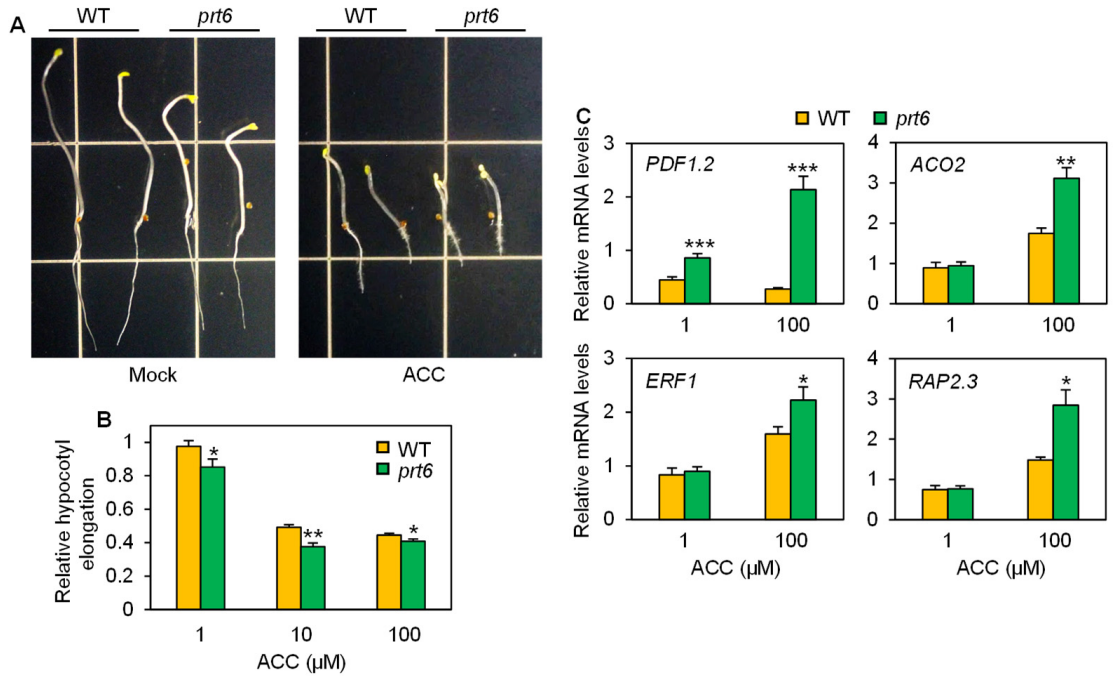

Figure 5. The prt6 mutation enhanced ethylene responsiveness. (A) Photos of wild-type (WT) and prt6 seedlings that were grown on half-strength MS media containing 0 (mock) or $10 \mu \mathrm{M}$ ACC for $5 \mathrm{~d}$ in the dark. (B) Relative hypocotyl elongation of WT and prt6 seedlings treated with ACC. Seeds were incubated on half-strength MS plates containing a range of ACC concentrations for $5 \mathrm{~d}$ in the dark. Hypocotyl length was measured using Image J software. Data represent means \pm SE $(n=24)$. (C) Relative mRNA levels of ethylene-responsive genes. Ten-day-old seedlings were treated with 1 or $100 \mu \mathrm{M}$ ACC for $6 \mathrm{~h}$. Relative hypocotyl elongation and mRNA levels were calculated by comparison to the corresponding genotype (WT or prt6) under mock (0 mM ACC) conditions. Data represent means $\pm \mathrm{SE}(\mathrm{n}=3)$. Asterisks indicate significant difference between WT and $p r t 6\left({ }^{*} p<0.05 ;{ }^{* *} p<0.01\right.$, *** $p<0.001)$.
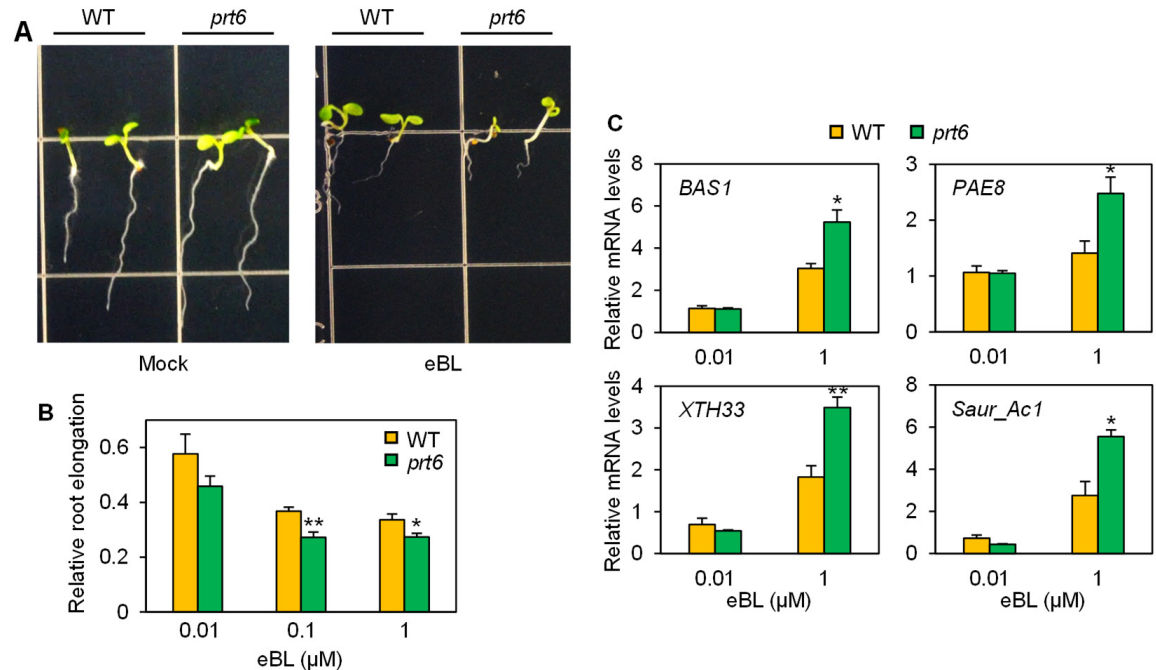

Figure 6. The prt6 mutation augmented brassinosteroid responsiveness. (A) Photos of WT (wild-type) and prt6 seedlings that were grown under mock $(0.02 \%$ ethanol) or 24-epibrassinolide (eBL; $1 \mu \mathrm{M}$ in $0.02 \%$ ethanol) for $5 \mathrm{~d}$. (B) Relative root elongation of WT and prt6 seedlings treated with eBL. Seeds were incubated on half-strength MS plates containing a range of eBL concentrations for $5 \mathrm{~d}$. Root length was measured using Image J software. Data represent means $\pm S E(n=18)$. (C) Relative mRNA levels of brassinosteroid-responsive genes. Ten-day-old seedlings were treated with eBL $(0.01$ or $1 \mu \mathrm{M}$ in $0.02 \%$ ethanol) for $6 \mathrm{~h}$. Relative root elongation and mRNA levels were calculated by comparison to the corresponding genotype (WT or prt6) under mock $(0.02 \%$ ethanol) conditions. Data represent means $\pm \mathrm{SE}(\mathrm{n}=3)$. Asterisks indicate significant difference between $\mathrm{WT}$ and prt6 $\left({ }^{*} p<0.05 ;{ }^{* *} p<0.01\right)$. 
2.4. The prt6 Mutation Activates ABA-Dependent and Independent Pathways Involved in Salinity/Osmotic Stress Tolerance

It has been widely accepted that adaptive responses to drought and salinity are regulated through ABA-dependent and independent pathways at the transcriptional level $[37,38]$. To determine if the prt6 mutation alters mRNA accumulation of transcription factors involved in ABA-dependent and independent pathways, the transcript levels of representative genes were monitored in the prt6 and WT seedlings by qRT-PCR (Figure 7A). Of the four ABSCISIC ACID-RESPONSIVE ELEMENT-BINDING PROTEINS/FACTORS (AREB/ABFs) in ABA-dependent pathways, ABF1, ABF3, and AREB2 mRNAs were more abundantly accumulated in the prt6 mutant than WT in at least one time point under salinity stress. Similarly, DEHYDRATION-RESPONSIVE ELEMENT-BINDING FACTOR 2A (DREB2A) and $D R E B 2 B$, representative transcription factors in ABA-independent pathways, were more highly induced by salinity stress in the mutant line relative to WT in at least one time point. In contrast with these results, the level of DREB2A transcript was higher in WT than the mutant line on day 0 , although the difference between the two genotypes was minimal. We also investigated the expression levels of dehydrin genes such as RESPONSIVE TO ABA 18 (RAB18), RESPONSIVE TO DESICCATION $29 A(R D 29 A)$, and $R D 29 B$, direct targets of $A R E B / A B F s$ and DREB2s [39,40]. All of these genes were highly induced in response to salinity, with greater expression in the prt6 mutant during salinity stress (Figure 7A). These results are in accordance with the expression patterns of their upstream transcription factors.
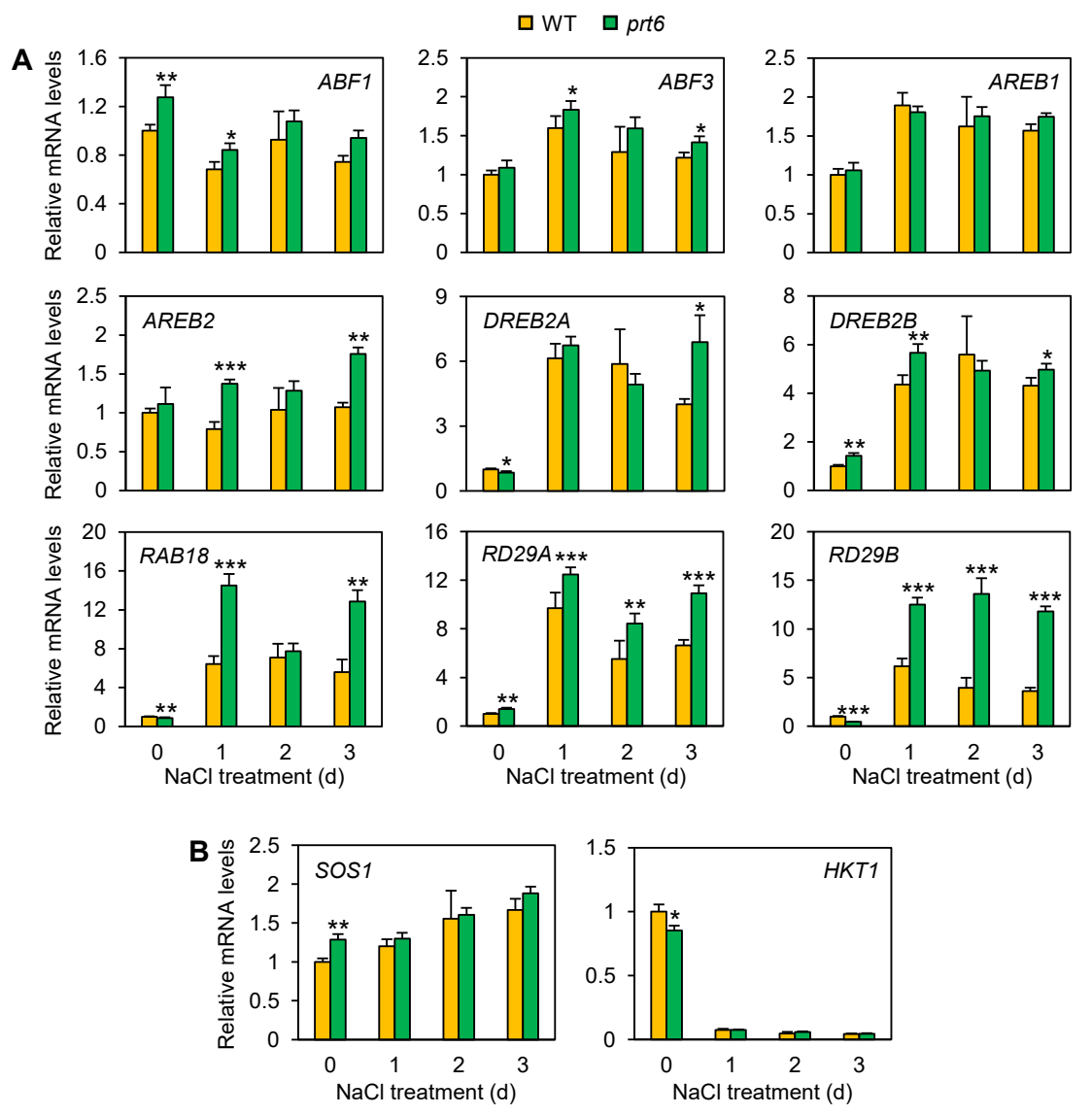

Figure 7. The prt6 mutation induced mRNA accumulation of genes associated with salinity tolerance. (A) Relative mRNA levels of transcription factors involved in ABA-dependent (AREB/ABFs) and independent (DREB2s) pathways of salinity/osmotic stress tolerance and their downstream genes, dehydrins. (B) Relative mRNA levels of sodium transporter genes. Ten-day-old seedlings were treated with $150 \mathrm{mM} \mathrm{NaCl}$ for up to $3 \mathrm{~d}$ and subjected to qRT-PCR analysis. Data represent means $\pm \mathrm{SE}(\mathrm{n}=3)$. Asterisks indicate significant difference between WT and prt6 $\left({ }^{*} p<0.05 ;{ }^{* *} p<0.01,{ }^{* * *} p<0.001\right)$. 
The prt6 mutant displayed restricted accumulation of $\mathrm{Na}^{+}$in root and shoot tissues (Figure 4). This data raised the question of whether the prt6 mutation affects the expression of genes associated with $\mathrm{Na}^{+}$transport. To answer this question, we monitored the mRNA accumulation of SALT OVERLY SENSITIVE 1 (SOS1) and HIGH-AFFINITY $K^{+}$TRANSPORTER 1 (HKT1) by qRT-PCR (Figure 7B). The level of SOS1 transcript was more abundant in the mutant than WT on day 0 , but no significant difference was observed in the two genotypes during salinity stress. The mRNA level of HKT1 was higher in WT than the mutant line on day 0, but its expression was drastically declined by salinity stress, with no significant difference between the two lines. These results suggest that low accumulation of $\mathrm{Na}^{+}$in mutant roots and shoots is not controlled through transcriptional regulation of these $\mathrm{Na}^{+}$transporters.

\subsection{The prt6 Mutation Induces ERF-VIIs at the mRNA Accumulation Level under Salinity Stress}

PRT6 encodes the last enzyme in the PRT6/N-degron pathway that regulates the turnover of ERF-VII proteins in Arabidopsis [21]. Therefore, a knockout mutation of prt6 increases the accumulation of ERF-VII proteins [12-14]. To determine the influence of the prt6 mutation in the expression of ERF-VIIs, we performed qRT-PCR analysis in the prt6 mutant and WT seedlings. Of the five ERF-VII genes, HYPOXIA RESPONSIVE ERF 1 (HRE1) and HRE2 have been demonstrated to be induced under oxygen deprivation [41-43]. Similar to the low oxygen response, these genes were upregulated by salinity stress in WT (Figure 8). In the prt6 mutant, HRE1 and HRE2 were constitutively expressed, and their mRNA level was significantly higher in the mutant than WT under non-stress (day 0) and salinity conditions (days 1 and 3). RAP2.2, RAP2.3, and RAP2.12 have not been demonstrated to be responsive to low oxygen $[41,43]$. Likewise, the transcript abundance of the three RAP2 genes was not clearly altered under salinity stress in the two genotypes, with higher mRNA accumulation of these genes in the prt6 mutant. ALCOHOL DEHYDROGENASE 1 (ADH1) is a downstream gene of most ERF-VIIs; overexpression of HRE1, RAP2.2, RAP2.3, or RAP2.12 upregulates the expression of $A D H 1$ even under non-stress conditions [41,43]. Consistent with the ERF-VII gene expression data presented here, $A D H 1$ transcript was highly accumulated in the prt6 mutant under non-stress and salinity conditions.
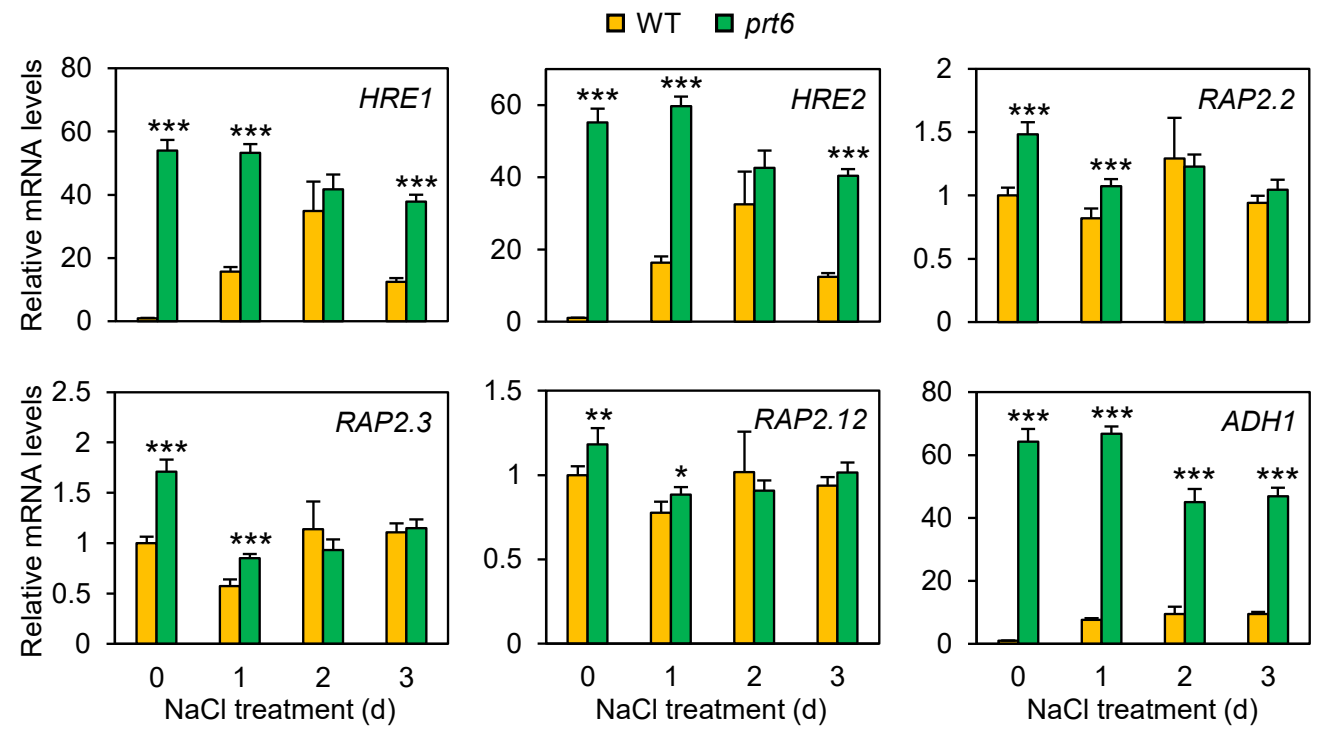

Figure 8. The prt6 mutation promoted mRNA accumulation of ERF-VII genes. Ten-day-old seedlings were treated with $150 \mathrm{mM} \mathrm{NaCl}$ for up to $3 \mathrm{~d}$ and subjected to qRT-PCR analysis. Data represent means \pm SE $(n=3)$. Asterisks indicate significant difference between WT and $p r t 6\left({ }^{*} p<0.05 ;{ }^{* *} p<0.01\right.$, $* * * p<0.001)$. 


\section{Discussion}

Salinity and flooding are closely related abiotic stressors which can occur sequentially or concurrently [2,5]. Therefore, simultaneous improvement of both salinity and flooding tolerance is a desirable trait in crop plants. The PRT6/N-degron pathway is the key signaling process that adversely regulates tolerance to flooding and low oxygen $[8,21]$. In the present study, we demonstrated that this pathway also plays a negative role in salinity tolerance at the seed germination to adult plant stages through detailed time-course and dose-response observations of the Arabidopsis prt6 mutant and wild-type plants. Functional characterization of the mutated prt6 uncovered the transcriptional and hormonal pathways coordinated by the PRT6/N-degron under high salt.

Ethylene is a crucial hormone that regulates plant responses and adaptation to salinity [29,30,32]. For example, exogenous application of an ethylene precursor, ACC, suppressed the accumulation of $\mathrm{Na}^{+}$in Arabidopsis roots and reduced membrane damage under excess salt [44]. In the eto1 mutant that constitutively overproduces ethylene, the $\mathrm{Na}^{+}$concentrations in both stelar cells and xylem sap were reduced under salinity, leading to enhanced plant survival and leaf chlorophyll content [45]. These results indicate that ethylene plays a pivotal role in limiting $\mathrm{Na}^{+}$uptake in roots and transport to shoots under high salt. Besides $\mathrm{Na}^{+}$influx/transport regulation, mutant and transgenic studies revealed that ethylene signaling is necessary for the salt-induced accumulation of dehydrin mRNAs such as RD29A, RD29B, and COLD-REGULATED 15A (COR15A) in Arabidopsis [46,47]. In the present study, we demonstrated that the prt6 mutation reduces $\mathrm{Na}^{+}$levels in both roots and shoots (Figure 4) and increases mRNA accumulation of dehydrins including $R D 29 A$ and $R B 29 B$ under salinity (Figure 7). It is anticipated that these adaptive responses enhanced by the prt6 mutation can be attributed to increased sensitivity to ethylene in the mutant (Figure 5).

BR is another positive regulator for salinity tolerance [31,48,49]. Treatment of barley and canola plants with eBL reduced $\mathrm{Na}^{+}$levels in roots and shoots, contributing to the maintenance of growth under salinity stress [50,51]. Application of eBL also promoted mRNA accumulation of RD29A in Arabidopsis under excess salt [52], whereas mRNA accumulation of this gene was restricted in a brassinosteroid deficient mutant, det2 [53]. These results indicate that $\mathrm{Na}^{+}$influx/transport and dehydrin gene expression under salinity stress were coordinated by BR as well as ethylene. It is expected that increased sensitivity to BR in the prt6 mutant (Figure 6) benefits restricted accumulation of $\mathrm{Na}^{+}$in roots and shoots and stimulated expression of dehydrin genes under high salt (Figures 4 and 7). The PRT6/N-degron pathway is responsible for proteasomal degradation of ERF-VII, VRN2, and ZPR2 proteins $[24,25,54]$, but this pathway may also regulate targeted proteolysis of other proteins. Further investigation is required to uncover how disruption of the PRT6/N-degron pathway enhances plant response to ethylene and BR through stabilization of ERF-VII, VRN2, ZPR2, and other unidentified proteins.

Previous studies showed that mutations in prt6 increase ABA sensitivity during germination and seedling establishment in Arabidopsis [11,19]. Transient expression and chromatin immunoprecipitation (ChIP) analyses demonstrated that RAP2-type ERF-VIIs directly interact with the promoter region of ABA INSENSITIVE 5 (ABI5), a major downstream transcription factor in the ABA signaling pathway, activating its expression [14]. Additionally, GUS staining assays showed that promABI5::GUS activity is induced in prt6 mutant seeds, but not in wild-type seeds. These data indicate that ABA hypersensitivity in prt6 mutants is caused by enhanced expression of $A B I 5$ via stabilization of its transcriptional regulators, RAP2-type ERF-VIIs. Our study revealed that the prt6 mutation increased mRNA accumulation of three AREB/ARF genes under excess salt (Figure 7). Similar to ABI5, AREB/ABFs serve as downstream transcription factors in the ABA signaling pathway. AREB/ABFs primarily regulate the expression of ABA-responsible genes associated with stress tolerance [55], whereas ABI5 coordinates the expression of ABA-responsive genes related to seed germination and dormancy [56]. It is anticipated that increased mRNA accumulation of $A R E B / A B F s$ in the prt6 mutant may be attributed to ERF-VII-mediated activation of their respective promoters. 
Although many stress-responsive genes are upregulated by ABA, these genes are also induced in an ABA-independent manner [55]. DREB2A and DREB2B are major transcription factors responsible for ABA-independent gene expression. Our study found that the prt6 mutation increases mRNA accumulation of $D R E B 2 A$ and $D R E B 2 B$ under high salt, accompanied by high expression of key ABA-dependent transcription factors including $A B F 1, A B F 3$, and $A R E B 2$ (Figure 7). A previous study demonstrated that the expression of DREB2A is regulated by direct binding of ABF3, AREB1, and AREB2 to its promoter region under osmotic stress [57]. It is likely that elevated accumulation of DREB2A mRNA in the prt6 mutant results from transcriptional activation mediated by ABF3 and AREB2.

The PRT6/N-end rule pathway regulates the turnover of all five ERF-VII proteins [12-14]. Thus, disruption of prt6, which encodes an essential enzyme of the proteolysis pathway, leads to overaccumulation of all five ERF-VII proteins. However, the impact of the prt6 mutation on mRNA accumulation of ERF-VII genes remains unknown. This study revealed that the prt6 mutation increases mRNA levels of all ERF-VII genes under salinity, along with the dramatic induction of $A D H$ mRNA, a downstream target of ERF-VII transcription factors (Figure 8). The expression patterns of HRE-type and RAP2-type ERF-VIIs were apparently distinct, reflecting the notion that these two types of ERF-VIIs function differently in the regulation of hypoxia-responsive gene expression and seed germination [14,58,59]. The mechanisms underlying overaccumulation of ERF-VII mRNAs in the prt6 mutant are unknown, but this process must assist the further synthesis of ERF-VII proteins.

The functional importance of ERF-VII genes and proteins in salinity tolerance has been previously reported. For example, transgenic and mutant analysis revealed that HRE2 is a positive regulator for salinity tolerance in Arabidopsis [60]. Vicente et al. [26] demonstrated that salinity tolerance conferred by the prt6 mutation is attributable to increased accumulation of ERF-VII proteins because the resilience was reverted in the prt6erfVII sextuple mutant that lacks PRT6 and all five ERF-VII genes. This report also suggested that high salt promotes the stabilization of ERF-VII proteins through a reduced synthesis of nitric oxide, an essential molecule for the targeted degradation of ERF-VIIs via the PRT6/N-degron pathway. These results emphasize that the PRT6/N-degron pathway regulation of ERF-VIIs plays a vital role in salinity tolerance in Arabidopsis. Further genetic and molecular analyses will determine the impact of this pathway in the regulation of ABA-dependent and independent processes and hormone response pathways under salinity stress.

We propose a model for salinity-tolerance mechanisms that are negatively regulated by the PRT6/N-degron pathway (Figure 9). When exposed to high salt, plants are damaged mainly due to salt-induced osmotic stress and sodium toxicity. The present study demonstrated that PRT6 restricts signaling processes associated with adaptation to both osmotic stress and sodium toxicity. For example, PRT6 downregulates mRNA accumulation of $A R E B / A B F s$ and DREB2s, well-characterized transcription factors involved in the ABA-dependent and independent pathways of osmotic stress tolerance, respectively. PRT6 also dampens responsiveness to ethylene and BR, key hormones that enhance the expression of stress-responsive genes such as dehydrins and restrict root $\mathrm{Na}^{+}$uptake and root-to-shoot $\mathrm{Na}^{+}$transport. In this model, we propose that RAP2-type ERF-VIIs serve as members of the ABA-dependent pathway, whereas HRE-type ERF-VIIs function in the ABA-independent pathway due to the following reasons: (1) All RAP2-type ERF-VII genes are ABA-responsive [43]. (2) The three RAP2-type ERF-VIIs directly regulate the expression of $A B I 5$, a downstream transcription factor in the ABA signaling pathway [14]. (3) Inducible expression of each of the three RAP2-type ERF-VIIs increases sensitivity to ABA [43]. (4) Both HRE-type ERF-VII genes are not ABA-inducible [43,61]. (5) HRE2 activates the expression of reporter genes by direct binding to the DRE/CRT motif, a cis-acting element in the ABA-independent pathway [62,63]. These data demonstrate that RAP2 and HRE-type ERF-VIIs belong to the ABA-dependent and independent pathways of osmotic/salinity stress tolerance, respectively. Based on the evidence (2), it is predicted that RAP2-type ERF-VIIs directly modulate the expression of $A R E B / A B F s$, other downstream transcription factors in the ABA signaling pathway. Taken together, these results have revealed that the PRT6/N-degron pathway acts as a negative regulator 
of salinity tolerance in Arabidopsis through modulation of transcriptional and hormonal responses to the stress. Many commercially important plants can encounter salinity and flooding sequentially or concurrently, reducing crop yield and quality under changing climates. Guided manipulation of the PRT6/N-degron pathway could form a promising approach to generate new crop varieties with improved tolerance to both salinity and flooding.

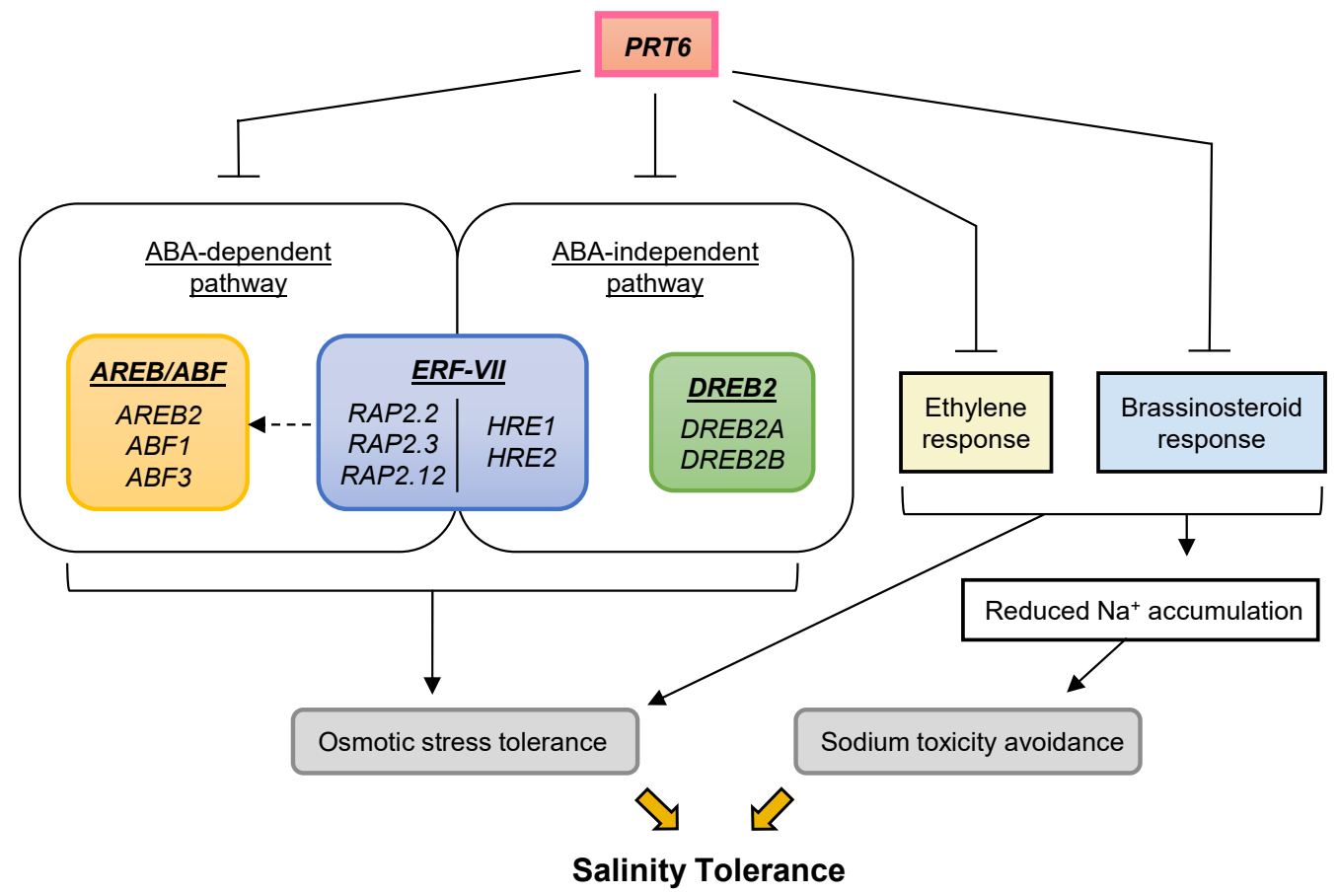

Figure 9. Model for salinity-tolerance mechanisms that are negatively regulated by the PRT6/N-degron pathway. A dashed line indicates a hypothetical relationship.

\section{Materials and Methods}

\subsection{Plant Materials and Growth Conditions}

Arabidopsis (Arabidopsis thaliana L.) Columbia-0 [wild-type (WT)] and its T-DNA insertion mutant, prt6-1, were obtained from the Arabidopsis Biological Resource Center at Ohio State University. The prt6-1 knockout mutant has been described previously [10-12,64]. These genotypes were propagated simultaneously under the same growth conditions $\left(23^{\circ} \mathrm{C}, 50 \%\right.$ relative humidity, $16 \mathrm{~h}$ day/ $/ 8 \mathrm{~h}$ dark, $120 \mu \mathrm{mol}$ photons $\left.\mathrm{m}^{-2} \mathrm{~s}^{-1}\right)$. Seeds were sterilized with $2 \%(w / v)$ sodium hypochlorite and $0.1 \%(v / v)$ Tween-20 for $12 \mathrm{~min}$ and then rinsed thoroughly using deionized water. The sterilized seeds were immersed in water at $4{ }^{\circ} \mathrm{C}$ for $4 \mathrm{~d}$ for synchronized germination.

\subsection{Salinity Stress and Hormone Treatments}

All stress and hormone treatments were replicated in at least three independent biological experiments under the growth conditions mentioned above. For germination tests, seeds were incubated on half-strength MS media containing $0,50,100$, or $150 \mathrm{mM} \mathrm{NaCl}$ for up to $5 \mathrm{~d}$. Seedlings with more than $1 \mathrm{~mm}$ roots were counted as germinated. To visualize root growth under salinity, root bending assays $[27,28]$ were performed. Four-day-old seedlings were transferred on half-strength MS media containing 0 or $150 \mathrm{mM} \mathrm{NaCl}$ and grown upside down for $4 \mathrm{~d}$. To quantify root growth under salinity, the root tip of the main root in each seedling was marked after transplanting of 4-day-old seedlings onto salt-containing media $(0-150 \mathrm{mM} \mathrm{NaCl})$. Following $4 \mathrm{~d}$ of vertical incubation, the length of root growth was measured. For seedling viability tests, 4-day-old seedling grown under non-stress conditions were transferred into half-strength MS media containing 0 or $200 \mathrm{mM} \mathrm{NaCl}$ and incubated 
for $4 \mathrm{~d}$. For adult plant viability tests, 4-day-old seedlings were grown in soil-containing pots for $21 \mathrm{~d}$. These pots were placed in a tray containing 0 or $200 \mathrm{mM} \mathrm{NaCl}$ for $12 \mathrm{~d}$.

Hormone treatments were performed by transferring 10-day-old seedlings on half-strength MS media supplemented with 1-aminocyclopropane-1-carboxylic acid (ACC; 0,1 , or $100 \mu \mathrm{M}$ ) or 24-epibrassinolide (eBL; $0,0.01$, or $1 \mu \mathrm{M}$ in $0.02 \%(v / v)$ ethanol) and incubating them for $6 \mathrm{~h}$.

\subsection{Chlorophyll and Anthocyanin Assays}

Chlorophyll and anthocyanin contents were determined using the methods of Porra [65] and Rabino and Mancinelli [66], respectively. Chlorophyll was extracted from $50 \mathrm{mg}$ of homogenized fresh tissues in $3 \mathrm{~mL}$ of $100 \%$ methanol on ice. Following centrifugation at $4{ }^{\circ} \mathrm{C}$ for $20 \mathrm{~min}$ at $21,000 \mathrm{~g}$, the absorbance of the supernatant was measured at 652.0 and $665.2 \mathrm{~nm}$ with a UV-Vis spectrophotometer. Anthocyanin was extracted from $200 \mathrm{mg}$ of homogenized fresh tissues by shaking the tissues in acidic methanol extraction buffer $[99 \%(v / v)$ methanol $+1 \%(v / v) \mathrm{HCl}]$ for $16 \mathrm{~h}$ at $4{ }^{\circ} \mathrm{C}$. After extraction, $0.4 \mathrm{~mL}$ of water and $0.4 \mathrm{~mL}$ of chloroform were added. Following centrifugation at $4{ }^{\circ} \mathrm{C}$ for $2 \mathrm{~min}$ at $21,000 \mathrm{~g}$, the absorbance of the supernatant was measured at 530 and $657 \mathrm{~nm}$.

\section{4. $\mathrm{Na}^{+}$and $\mathrm{K}^{+}$Content Analysis}

Sodium and potassium ion concentrations were quantified using the method of Rus et al. [67]. Four-day-old seedlings were grown in pots containing Turface MVP (Turface Athletics, Buffalo Grove, IL, USA) for $21 \mathrm{~d}$. These pots were placed in a tray containing 0 or $200 \mathrm{mM} \mathrm{NaCl}$, and shoot and root tissues were harvested on the specified days. The harvested tissues were washed using deionized water and dried at $65^{\circ} \mathrm{C}$ for $2 \mathrm{~d}$. Tissues ( $100 \mathrm{mg}$ dry weight) were then homogenized in $20 \mathrm{~mL}$ of $0.1 \mathrm{~N}$ $\mathrm{HNO}_{3}$ for $30 \mathrm{~min}$. Following filtration with quantitative analysis-grade filter paper, the extract was subjected to $\mathrm{Na}^{+}$and $\mathrm{K}^{+}$analysis using an inductively coupled plasma atomic emission spectrometer (ICP-AES).

\subsection{Hormone Sensitivity Evaluation}

For ethylene response analysis, seeds were incubated on half-strength MS media containing 0, 1 , 10 , or $100 \mu \mathrm{M}$ ACC in the dark for $5 \mathrm{~d}$. For brassinosteroid response analysis, seeds were grown on half-strength MS media containing $0,0.01,0.1$, or $1 \mu \mathrm{M} \mathrm{eBL}$ in the light $\left(120 \mu \mathrm{mol} \mathrm{m}^{-2} \mathrm{~s}^{-1}\right)$ for $5 \mathrm{~d}$. After incubation, hypocotyl and root length was measured using Image J software [68].

\subsection{Quantitative RT-PCR Analysis}

Total RNA was extracted from $100 \mathrm{mg}$ (fresh weight) of seeding tissue using RNeasy Plant Mini kit (Qiagen, Hilden, Germany). Genomic DNA was eliminated by the on-column digestion method described by the manufacturer's protocol. cDNA was synthesized from $2 \mu \mathrm{g}$ of total RNA as described by Fukao et al. [69]. Real-time RT-PCR was conducted in a $15 \mu \mathrm{L}$ reaction using iTaq Universal SYBR Green Supermix (Bio-Rad, Hercules, CA, USA) in the CFX Connect real-time PCR detection system (Bio-Rad). Amplification specificity was validated by melt-curve analysis at the end of each PCR experiment. Relative transcript abundance was determined using the comparative cycle threshold method [70]. Primer sequences used for this analysis are listed in Table S1. UBQ10 (AT4G05320) and 18s RNA (AT2G01010) genes were used as internal controls. qRT-PCR was repeated three times using tissues generated from three independent plant culture under identical growth conditions.

Supplementary Materials: The following are available online at http://www.mdpi.com/2223-7747/9/11/1415/s1, Table S1: Primer sequences used for quantitative RT-PCR.

Author Contributions: Conceptualization, T.F.; Investigation, S.L., J.B.A., A.H. and T.F.; Data analysis, S.L., J.B.A. and T.F.; Writing, S.L. and T.F.; Project administration, T.F.; Funding acquisition, T.F. All authors have read and agreed to the published version of the manuscript. 
Funding: This research was funded by the Institute for Critical Technology and Applied Science of Virginia Tech; the Virginia Agricultural Experiment Station; and the Hatch Program of the National Institute of Food and Agriculture, U.S. Department of Agriculture.

Acknowledgments: We thank Hayden Quilty for technical assistance.

Conflicts of Interest: The authors declare no conflict of interest.

\section{References}

1. Munns, R.; Tester, M. Mechanisms of salinity tolerance. Annu. Rev. Plant Biol. 2008, 59, 651-681. [CrossRef] [PubMed]

2. Barrett-Lennard, E.G. The interaction between waterlogging and salinity in higher plants: Causes, consequences and implications. Plant Soil 2003, 253, 35-54. [CrossRef]

3. Chen, C.-C.; McCarl, B.; Chang, C.-C. Climate change, sea level rise and rice: Global market implications. Clim. Change 2012, 110, 543-560. [CrossRef]

4. Hoggart, S.P.G.; Hanley, M.E.; Parker, D.J.; Simmonds, D.J.; Bilton, D.T.; Filipova-Marinova, M.; Franklin, E.L.; Kotsev, I.; Penning-Rowsell, E.C.; Rundle, S.D.; et al. The consequences of doing nothing: The effects of seawater flooding on coastal zones. Coast. Eng. 2014, 87, 169-182. [CrossRef]

5. Hanley, M.E.; Sanders, S.K.D.; Stanton, H.M.; Billington, R.A.; Boden, R. A pinch of salt: Response of coastal grassland plants to simulated seawater inundation treatments. Ann. Bot. 2019, 125, 265-276. [CrossRef]

6. Varshavsky, A. The N-end rule pathway and regulation by proteolysis. Protein Sci. 2011, 20, 1298-1345. [CrossRef]

7. Dissmeyer, N. Conditional protein function via N-degron pathway-mediated proteostasis in stress physiology. Annu. Rev. Plant Biol. 2019, 70, 83-117. [CrossRef]

8. Gibbs, D.J.; Bacardit, J.; Bachmair, A.; Holdsworth, M.J. The eukaryotic N-end rule pathway: Conserved mechanisms and diverse functions. Trends Cell Biol. 2014, 24, 603-611. [CrossRef]

9. Yoshida, S.; Ito, M.; Callis, J.; Nishida, I.; Watanabe, M. A delayed leaf senescence mutant is defective in arginyl-tRNA: Protein arginyltransferase, a component of the N-end rule pathway in Arabidopsis. Plant J. 2002, 32, 129-137. [CrossRef]

10. Graciet, E.; Walter, F.; Maoileidigh, D.O.; Pollmann, S.; Meyerowitz, E.M.; Varshavsky, A.; Wellmer, F. The $\mathrm{N}$-end rule pathway controls multiple functions during Arabidopsis shoot and leaf development. Proc. Natl. Acad. Sci. USA 2009, 106, 13618-13623. [CrossRef]

11. Holman, T.J.; Jones, P.D.; Russell, L.; Medhurst, A.; Tomas, S.U.; Talloji, P.; Marquez, J.; Schmuths, H.; Tung, S.A.; Taylor, I.; et al. The N-end rule pathway promotes seed germination and establishment through removal of ABA sensitivity in Arabidopsis. Proc. Natl. Acad. Sci. USA 2009, 106, 4549-4554. [CrossRef]

12. Gibbs, D.J.; Lee, S.C.; Isa, N.M.; Gramuglia, S.; Fukao, T.; Bassel, G.W.; Correia, C.S.; Corbineau, F.; Theodoulou, F.L.; Bailey-Serres, J.; et al. Homeostatic response to hypoxia is regulated by the N-end rule pathway in plants. Nature 2011, 479, 415-418. [CrossRef] [PubMed]

13. Licausi, F.; Kosmacz, M.; Weits, D.A.; Giuntoli, B.; Giorgi, F.M.; Voesenek, L.A.; Perata, P.; van Dongen, J.T. Oxygen sensing in plants is mediated by an N-end rule pathway for protein destabilization. Nature 2011, 479, 419-422. [CrossRef]

14. Gibbs, D.J.; Isa, N.M.; Movahedi, M.; Lozano-Juste, J.; Mendiondo, G.M.; Berckhan, S.; Rosa, N.M.; Conde, J.V.; Correia, C.S.; Pearce, S.P.; et al. Nitric oxide sensing in plants is mediated by proteolytic control of group VII ERF transcription factors. Mol. Cell 2014, 53, 369-379. [CrossRef]

15. Weits, D.A.; Giuntoli, B.; Kosmacz, M.; Parlanti, S.; Hubberten, H.M.; Riegler, H.; Hoefgen, R.; Perata, P.; van Dongen, J.T.; Licausi, F. Plant cysteine oxidases control the oxygen-dependent branch of the N-end-rule pathway. Nat. Commun. 2014, 5, 3425. [CrossRef]

16. Abbas, M.; Berckhan, S.; Rooney, D.J.; Gibbs, D.J.; Conde, J.V.; Correia, C.S.; Bassel, G.W.; Rosa, N.M.; Leon, J.; Alabadi, D.; et al. Oxygen sensing coordinates photomorphogenesis to facilitate seedling survival. Curr. Biol. 2015, 25, 1483-1488. [CrossRef]

17. Riber, W.; Muller, J.T.; Visser, E.J.; Sasidharan, R.; Voesenek, L.A.; Mustroph, A. The greening after extended darkness1 is an N-end rule pathway mutant with high tolerance to submergence and starvation. Plant Physiol. 2015, 167, 1616-1629. [CrossRef] 
18. Gravot, A.; Richard, G.; Lime, T.; Lemarie, S.; Jubault, M.; Lariagon, C.; Lemoine, J.; Vicente, J.; Robert-Seilaniantz, A.; Holdsworth, M.J.; et al. Hypoxia response in Arabidopsis roots infected by Plasmodiophora brassicae supports the development of clubroot. BMC Plant Biol. 2016, 16, 251. [CrossRef]

19. Zhang, H.; Gannon, L.; Jones, P.D.; Rundle, C.A.; Hassall, K.L.; Gibbs, D.J.; Holdsworth, M.J.; Theodoulou, F.L. Genetic interactions between ABA signalling and the Arg/N-end rule pathway during Arabidopsis seedling establishment. Sci. Rep. 2018, 8, 15192. [CrossRef]

20. Vicente, J.; Mendiondo, G.M.; Pauwels, J.; Pastor, V.; Izquierdo, Y.; Naumann, C.; Movahedi, M.; Rooney, D.; Gibbs, D.J.; Smart, K.; et al. Distinct branches of the N-end rule pathway modulate the plant immune response. New Phytol. 2019, 221, 988-1000. [CrossRef]

21. Bailey-Serres, J.; Fukao, T.; Gibbs, D.J.; Holdsworth, M.J.; Lee, S.C.; Licausi, F.; Perata, P.; Voesenek, L.A.C.J.; van Dongen, J.T. Making sense of low oxygen sensing. Trends Plant Sci. 2012, 17, 129-138. [CrossRef] [PubMed]

22. Tamang, B.G.; Fukao, T. Plant adaptation to multiple stresses during submergence and following desubmergence. Int. J. Mol. Sci. 2015, 16, 30164-30180. [CrossRef] [PubMed]

23. Gibbs, D.J.; Bailey, M.; Tedds, H.M.; Holdsworth, M.J. From start to finish: Amino-terminal protein modifications as degradation signals in plants. New Phytol. 2016, 211, 1188-1194. [CrossRef] [PubMed]

24. Gibbs, D.J.; Tedds, H.M.; Labandera, A.M.; Bailey, M.; White, M.D.; Hartman, S.; Sprigg, C.; Mogg, S.L.; Osborne, R.; Dambire, C.; et al. Oxygen-dependent proteolysis regulates the stability of angiosperm polycomb repressive complex 2 subunit VERNALIZATION 2. Nat. Commun. 2018, 9, 5438. [CrossRef]

25. Weits, D.A.; Kunkowska, A.B.; Kamps, N.C.; Portz, K.M.; Packbier, N.K.; Venza, Z.N.; Gaillochet, C.; Lohmann, J.U.; Pedersen, O.; van Dongen, J.T.; et al. An apical hypoxic niche sets the pace of shoot meristem activity. Nature 2019, 569, 714. [CrossRef]

26. Vicente, J.; Mendiondo, G.M.; Movahedi, M.; Peirats-Llobet, M.; Juan, Y.T.; Shen, Y.Y.; Dambire, C.; Smart, K.; Rodriguez, P.L.; Charng, Y.; et al. The Cys-Arg/N-End Rule Pathway Is a General Sensor of Abiotic Stress in Flowering Plants. Curr. Biol. 2017, 27, 3183-3190.e3184. [CrossRef]

27. Wu, S.J.; Ding, L.; Zhu, J.K. SOS1, a genetic locus essential for salt tolerance and potassium acquisition. Plant Cell 1996, 8, 617-627. [CrossRef]

28. Lee, E.K.; Kwon, M.; Ko, J.H.; Yi, H.; Hwang, M.G.; Chang, S.; Cho, M.H. Binding of sulfonylurea by AtMRP5, an Arabidopsis multidrug resistance-related protein that functions in salt tolerance. Plant Physiol. 2004, 134, 528-538. [CrossRef]

29. Archard, P.; Cheng, H.; Grauwe, L.D.; Decat, J.; Schoutteten, H.; Moritz, T.; Van Der Straeten, D.; Peng, J.; Harberd, N.P. Integration of plant responses to environmentally activated phytohormonal signals. Science 2006, 311, 91-94. [CrossRef]

30. Cao, W.H.; Liu, J.; He, X.J.; Mu, R.L.; Zhou, H.L.; Chen, S.Y.; Zhang, J.S. Modulation of ethylene responses affects plant salt-stress responses. Plant Physiol. 2007, 143, 707-719. [CrossRef]

31. Vriet, C.; Russinova, E.; Reuzeau, C. Boosting crop yields with plant steroids. Plant Cell 2012, $24,842-857$. [CrossRef] [PubMed]

32. Peng, J.; Li, Z.; Wen, X.; Li, W.; Shi, H.; Yang, L.; Zhu, H.; Guo, H. Salt-induced stabilization of EIN3/EIL1 confers salinity tolerance by deterring ROS accumulation in Arabidopsis. PLoS Genet. 2014, 10, e1004664. [CrossRef] [PubMed]

33. Solano, R.; Stepanova, A.; Chao, Q.; Ecker, J.R. Nuclear events in ethylene signaling: A transcriptional cascade mediated by ETHYLENE-INSENSITIVE3 and ETHYLENE-RESPONSE-FACTOR1. Genes Dev. 1998, 12, 3703-3714. [CrossRef] [PubMed]

34. Deslauriers, S.D.; Alvarez, A.A.; Lacey, R.F.; Binder, B.M.; Larsen, P.B. Dominant gain-of-function mutations in transmembrane domain III of ERS1 and ETR1 suggest a novel role for this domain in regulating the magnitude of ethylene response in Arabidopsis. New Phytol. 2015, 208, 442-455. [CrossRef]

35. Goda, H.; Shimada, Y.; Asami, T.; Fujioka, S.; Yoshida, S. Microarray analysis of brassinosteroid-regulated genes in Arabidopsis. Plant Physiol. 2002, 130, 1319-1334. [CrossRef]

36. Fan, X.Y.; Sun, Y.; Cao, D.M.; Bai, M.Y.; Luo, X.M.; Yang, H.J.; Wei, C.Q.; Zhu, S.W.; Sun, Y.; Chong, K.; et al. BZS1, a B-box protein, promotes photomorphogenesis downstream of both brassinosteroid and light signaling pathways. Mol. Plant 2012, 5, 591-600. [CrossRef] 
37. Zhu, J.; Gong, Z.; Zhang, C.; Song, C.P.; Damsz, B.; Inan, G.; Koiwa, H.; Zhu, J.K.; Hasegawa, P.; Bressan, R.A. OSM1/SYP61: A syntaxin protein in Arabidopsis controls abscisic acid-mediated and non-abscisic acid-mediated responses to abiotic stress. Plant Cell 2002, 14, 3009-3028. [CrossRef]

38. Shinozaki, K.; Yamaguchi-Shinozaki, K. Gene networks involved in drought stress response and tolerance. J. Exp. Bot. 2007, 58, 221-227. [CrossRef]

39. Sakuma, Y.; Maruyama, K.; Osakabe, Y.; Qin, F.; Seki, M.; Schinozaki, K.; Yamaguchi-Shinozaki, K. Functinal analysis of an Arabidopsis transcription factor, DREB2A, involved in drought-responsive gene expression. Plant Cell 2006, 18, 1292-1309. [CrossRef]

40. Yoshida, T.; Fujita, Y.; Maruyama, K.; Mogami, J.; Todaka, D.; Shinozaki, K.; Yamaguchi-Shinozaki, K. Four Arabidopsis AREB/ABF transcription factors function predominantly in gene expression downstream of SnRK2 kinases in abscisic acid signalling in response to osmotic stress. Plant Cell Environ. 2015, 38, 35-49. [CrossRef]

41. Licausi, F.; van Dongen, J.T.; Giuntoli, B.; Novi, G.; Santaniello, A.; Geigenberger, P.; Perata, P. HRE1 and HRE2, two hypoxia-inducible ethylene response factors, affect anaerobic responses in Arabidopsis thaliana. Plant J. 2010, 62, 302-315. [CrossRef] [PubMed]

42. Hess, N.; Klode, M.; Anders, M.; Sauter, M. The hypoxia responsive transcription factor genes ERF71/HRE2 and ERF73/HRE1 of arabidopsis are differentially regulated by ethylene. Physiol. Plant. 2011, 143, 41-49. [CrossRef] [PubMed]

43. Papdi, C.; Perez-Salamo, I.; Joseph, M.P.; Giuntoli, B.; Bogre, L.; Koncz, C.; Szabados, L. The low oxygen, oxidative and osmotic stress responses synergistically act through the ethylene response factor VII genes RAP2.12, RAP2.2 and RAP2.3. Plant J. 2015, 82, 772-784. [CrossRef] [PubMed]

44. Li, J.; Jia, H.; Wang, J. cGMP and ethylene are involved in maintaining ion homeostasis under salt stress in Arabidopsis roots. Plant Cell Rep. 2014, 33, 447-459. [CrossRef]

45. Jiang, C.; Belfield, E.J.; Cao, Y.; Smith, J.A.; Harberd, N.P. An Arabidopsis soil-salinity-tolerance mutation confers ethylene-mediated enhancement of sodium/potassium homeostasis. Plant Cell 2013, 25, 3535-3552. [CrossRef]

46. Wang, Y.; Liu, C.; Li, K.; Sun, F.; Hu, H.; Li, X.; Zhao, Y.; Han, C.; Zhang, W.; Duan, Y.; et al. Arabidopsis EIN2 modulates stress response through abscisic acid response pathway. Plant Mol. Biol. 2007, 64, 633-644. [CrossRef]

47. Zhang, L.; Li, Z.; Quan, R.; Li, G.; Wang, R.; Huang, R. An AP2 domain-containing gene, ESE1, targeted by the ethylene signaling component EIN3 is important for the salt response in Arabidopsis. Plant Physiol. 2011, 157, 854-865. [CrossRef]

48. Li, F.; Asami, T.; Wu, X.; Tsang, E.W.; Cutler, A.J. A putative hydroxysteroid dehydrogenase involved in regulating plant growth and development. Plant Physiol. 2007, 145, 87-97. [CrossRef]

49. Cui, F.; Liu, L.; Zhao, Q.; Zhang, Z.; Li, Q.; Lin, B.; Wu, Y.; Tang, S.; Xie, Q. Arabidopsis ubiquitin conjugase $\mathrm{UBC} 32$ is an ERAD component that functions in brassinosteroid-mediated salt stress tolerance. Plant Cell 2012, 24, 233-244. [CrossRef]

50. Liu, J.; Gao, H.; Wang, X.; Zheng, Q.; Wang, C.; Wang, X.; Wang, Q. Effects of 24-epibrassinolide on plant growth, osmotic regulation and ion homeostasis of salt-stressed canola. Plant Biol. 2014, 16, 440-450. [CrossRef]

51. Azhar, N.; Su, N.; Shabala, L.; Shabala, S. Exogenously Applied 24-Epibrassinolide (EBL) Ameliorates Detrimental Effects of Salinity by Reducing K+ Efflux via Depolarization-Activated K+ Channels. Plant Cell Physiol. 2017, 58, 802-810. [CrossRef] [PubMed]

52. Kagale, S.; Divi, U.K.; Krochko, J.E.; Keller, W.A.; Krishna, P. Brassinosteroid confers tolerance in Arabidopsis thaliana and Brassica napus to a range of abiotic stresses. Planta 2007, 225, 353-364. [CrossRef]

53. Zeng, H.; Tang, Q.; Hua, X. Arabidopsis brassinosteroid mutants det2-1 and bin2-1 display altered salt tolerance. J. Plant Growth Regul. 2010, 29, 44-52. [CrossRef]

54. Gibbs, D.J.; Conde, J.V.; Berckhan, S.; Prasad, G.; Mendiondo, G.M.; Holdsworth, M.J. Group VII ethylene response factors Coordinate oxygen and nitric oxide signal transduction and stress responses in plants. Plant Physiol. 2015, 169, 23-31. [CrossRef] [PubMed]

55. Yoshida, T.; Mogami, J.; Yamaguchi-Shinozaki, K. ABA-dependent and ABA-independent signaling in response to osmotic stress in plants. Curr. Opin. Plant. Biol. 2014, 21, 133-139. [CrossRef] [PubMed] 
56. Skubacz, A.; Daszkowska-Golec, A.; Szarejko, I. The role and regulation of ABI5 (ABA-Insensitive 5) in plant development, abiotic stress responses and phytohormone crosstalk. Front. Plant. Sci. 2016, 7, 1884. [CrossRef] [PubMed]

57. Kim, J.S.; Mizoi, J.; Yoshida, T.; Fujita, Y.; Nakajima, J.; Ohori, T.; Todaka, D.; Nakashima, K.; Hirayama, Y.; Shinozaki, K.; et al. An ABRE promoter sequence is involved in osmotic stress-responsive expression of the DREB2A gene, which encodes a transcription factor regulating drought-inducible genes in Arabidopsis. Plant Cell Physiol. 2011, 52, 2136-2146. [CrossRef] [PubMed]

58. Bui, L.T.; Giuntoli, B.; Kosmacz, M.; Parlanti, S.; Licausi, F. Constitutively expressed ERF-VII transcription factors redundantly activate the core anaerobic response in Arabidopsis thaliana. Plant Sci. 2015, 236, 37-43. [CrossRef]

59. Gasch, P.; Fundinger, M.; Muller, J.T.; Lee, T.; Bailey-Serres, J.; Mustroph, A. Redundant ERF-VII transcription factors bind to an evolutionarily conserved cis-motif to regulate hypoxia-responsive gene expression in arabidopsis. Plant Cell 2016, 28, 160-180. [CrossRef]

60. Park, H.Y.; Seok, H.Y.; Woo, D.H.; Lee, S.Y.; Tarte, V.N.; Lee, E.H.; Lee, C.H.; Moon, Y.H. AtERF71/HRE2 transcription factor mediates osmotic stress response as well as hypoxia response in Arabidopsis. Biochem. Biophys. Res. Commun. 2011, 414, 135-141. [CrossRef]

61. Yang, C.Y.; Hsu, F.C.; Li, J.P.; Wang, N.N.; Shih, M.C. The AP2/ERF transcription factor AtERF73/HRE1 modulates ethylene responses during hypoxia in Arabidopsis. Plant Physiol. 2011, 156, 202-212. [CrossRef] [PubMed]

62. Narusaka, Y.; Nakashima, K.; Shinwari, Z.K.; Sakuma, Y.; Furihata, T.; Abe, H.; Narusaka, M.; Shinozaki, K.; Yamaguchi-Shinozaki, K. Interaction between two cis-acting elements, ABRE and DRE, in ABA-dependent expression of Arabidopsis rd29A gene in response to dehydration and high-salinity stresses. Plant J. 2003, 34, 137-148. [CrossRef] [PubMed]

63. Lee, S.Y.; Hwang, E.Y.; Seok, H.Y.; Tarte, V.N.; Jeong, M.S.; Jang, S.B.; Moon, Y.H. Arabidopsis AtERF71/HRE2 functions as transcriptional activator via cis-acting GCC box or DRE/CRT element and is involved in root development through regulation of root cell expansion. Plant Cell Rep. 2015, 34, 223-231. [CrossRef] [PubMed]

64. Garzon, M.; Eifler, K.; Faust, A.; Scheel, H.; Hofmann, K.; Koncz, C.; Yephremov, A.; Bachmair, A. PRT6/At5g02310 encodes an Arabidopsis ubiquitin ligase of the N-end rule pathway with arginine specificity and is not the CER3 locus. FEBS Lett. 2007, 581, 3189-3196. [CrossRef] [PubMed]

65. Porra, R.J. The chequered history of the development and use of simultaneous equations for the accurate determination of chlorophylls a and b. Photosynth. Res. 2002, 73, 149-156. [CrossRef] [PubMed]

66. Rabino, I.; Mancinelli, A.L. Light, temperature, and anthocyanin production. Plant Physiol. 1986, 81, 922-924. [CrossRef]

67. Rus, A.; Yokoi, S.; Sharkhuu, A.; Reddy, M.; Lee, B.H.; Matsumoto, T.K.; Koiwa, H.; Zhu, J.K.; Bressan, R.A.; Hasegawa, P.M. AtHKT1 is a salt tolerance determinant that controls $\mathrm{Na}^{+}$entry into plant roots. Proc. Natl. Acad. Sci. USA 2001, 98, 14150-14155. [CrossRef]

68. Schneider, C.A.; Rasband, W.S.; Eliceiri, K.W. NIH Image to ImageJ: 25 years of image analysis. Nature Methods 2012, 9, 671-675. [CrossRef]

69. Fukao, T.; Xu, K.; Ronald, P.C.; Bailey-Serres, J. A variable cluster of ethylene response factor-like genes regulates metabolic and developmental acclimation responses to submergence in rice. Plant Cell 2006, 18, 2021-2034. [CrossRef]

70. Livak, K.J.; Schmittgen, T.D. Analysis of relative gene expression data using real-time quantitative PCR and the 2(-Delta Delta C(T)) Method. Methods 2001, 25, 402-408. [CrossRef]

Publisher's Note: MDPI stays neutral with regard to jurisdictional claims in published maps and institutional affiliations. 